\title{
I. B. Moprayos
}

\section{ЗАВДАННЯ УДОСКОНАЛЕННЯ ДЕРЖАВНОї ІННОВАЦИйНОї ПОЛІТИКИ РОЗВИТКУ ВІТчИЗНЯНИХ HAYKOBO-TEXHIЧHKX CИCTEM}

У статті конкретизовано завдання удосконалення державної інноващійної політики розвитку вітчизняних науково-технічних систем за допомогою економіко-математичного моделювання.

Ключові слова: науково-технічні системи, державна інноваційна політика, інвестиції, національне господарство.

\section{1. Ветуп}

Дослідження, про які йдеться в доповіді, відносяться до спеціальності економіка та управління національним господарством. Вітчизняні науковотехнічні системи відіграють певну роль в розвитку національного господарства, що робить необхідним державне регулювання їх діяльності з метою покращення їх впливу на інші сектори економіки. В свою чергу ефективне державне регулювання вітчизняних науково-технічних систем має базуватися на результатах всебічних досліджень їх особливостей.

\section{2. Постановка проблеми}

Удосконалення державного регулювання вітчизняних науково-технічних систем має починатися 3 конкретизації завдань, вирішення яких призведе до бажаного результату. Формулювання відповідних завдань буде більш якісним, коли застосовується економіко-математичне моделювання, що дозволяє здійснювати кількісну оцінку.

\section{3. Осковна частина}

3.1. Аналіз пітературних джерел за темою дослідження. Розвиток національного господарства відбувається завдяки реалізації інноваційно-інвестиційних проектів, чому мають сприяти вітчизняні науково-технічні системи. Питання інноваційно-інвестиційної діяльності підприємств як на мікро-, так і на макрорівні досить глибоко і грунтовно розкрито в роботах вітчизняного вченого В. М. Гончарова [1-7]. В роботах професора В. М. Гончарова у співавторстві з іншими видатними вченими розкрито сутність інвестиційних ресурсів та їх регулювання; фактори та умови підвищення ефективності інноваційно-інвестиційної діяльності підприємств; теоретичні основи управління іх інноваційним потенціалом та зростання рівня інвестиційної привабливості регіону тощо.
Значна частина наукових здобутків, що викладені в роботах професора В. М. Гончарова [1-7], дістало стадії практичного використання, було впроваджено в навчальний процес, використано здобувачами у своїх наукових роботах. Незважаючи на глибину наукових розробок професора В. М. Гончарова та вчених його наукової школи, в якості важливого напряму логічного продовження відповідних наукових робіт за напрямом можна виділити питання удосконалення державного регулювання вітчизняних науково-технічних систем 3 метою покращення рівня ї впливу на інноваційно-інвестиційну діяльність підприємств.

3.2. Результати дослідженъ. Зростання інвестицій в економіку національного господарства $(\Delta I)$ $€$ чинником збільшення доходів підприємств підприємницького сектору економіки ( $\left.\Delta Д_{\Pi C}\right)$. Останнє, в свою чергу, призводить до збільшення податкових надходжень до державного та місцевих бюджетів $\left(\Delta \Pi_{\mathrm{H}}\right)$. Математично таку залежність можна виразити наступною моделлю:

$$
\Delta I \rightarrow \Delta Д_{\Pi \mathrm{C}} \rightarrow \Delta \Pi_{\mathrm{H}} \rightarrow \max .
$$

В ідеальному варіанті результати діяльності вітчизняних науково-технічних систем мають характеризуватися функціональною залежністю з обсягом інвестицій в розвиток національного господарства:

$$
I_{\text {зал }}=F\left(\text { РД }_{\text {НTC }}\right),
$$

де $I_{\text {зал }}$ - обсяг інвестицій, що залежить від результатів діяльності вітчизняних науково-технічних систем, грн.; РД Нтс - результати діяльності вітчизняних науково-технічних систем. Таких результатів діяльності може бути декілька.

Оскільки частина інвестицій залежить від діяльності вітчизняних науково-технічних систем, то інша частина не є залежною. Тоді загальний обсяг інвестицій в розвиток національного господарства $\left(I_{\text {заг }}\right)$ складається з суми цих частин:

$$
I_{\text {заг }}=I_{\text {нез }}+I_{\text {зал }},
$$


де $I_{\text {нез }}$ - обсяг інвестицій, що не залежить від діяльності вітчизняних науково-технічних систем.

В якості умови удосконалення функціонування вітчизняних науково-технічних систем можна сформулювати наступну: $I_{\text {зал }} \rightarrow \max$. Тоді частковим показником ефективності державної інноваційної політики розвитку вітчизняних науково-технічних систем можна розглядати наступну модель:

$$
\frac{I_{\text {зал } 0}}{I_{\text {заг } 0}}<\frac{I_{\text {зал} 1}}{I_{\text {заг } 1}},
$$

де індекси 1 та 0 відповідають наступному та попередньому періодам часу.

Вищенаведений показник характеризує частку залежних інвестицій в загальному їх обсязі. Якщо в якості основних результатів діяльності вітчизняних науково-технічних систем можна розглядати наступні показники, а саме: вартісний обсяг виконаних наукових і науково-технічних робіт $\left(O_{\text {Hтр }}\right)$; вартісний обсяг виконаних робіт організаціями сфери інжинірингу (О Ор $)$; кількість виконаних наукових і науково-технічних робіт $\left(N_{\mathrm{HTP}}\right)$; кількість друкованих робіт $\left(N_{\text {дР }}\right)$; кількість отриманих охоронних документів на права інтелектуальної власності у державному Департаменті інтелектуальної власності України $\left(N_{\text {Од }}\right)-$ то функціональна залежність обсягу інвестицій може бути сформульована наступним чином:

$$
I_{\text {зал }}=a \cdot O_{\mathrm{HTP}}^{\alpha}+b \cdot O_{\text {ПР }}^{\beta}+A N_{\mathrm{HTP}}^{\gamma}+d \cdot N_{\text {ДР }}^{\delta}+5 \cdot N_{\mathrm{OД}}^{\lambda},
$$

де $a, b, c, d, e-$ коефіцієнти рівняння при змінних. наведені коефіцієнти з одного боку показують кут нахилу прямої, а з іншого рівень залежності обсягу інвестицій від певного результату діяльності науковотехнічних систем. Чим більше значення коефіцієнта рівняння при певному аргументі, тим більше обсяг інвестицій залежить від відповідного показника.

$\alpha, \beta, \gamma, \delta, \lambda-$ коефіцієнти, що показують ступеневу залежність досліджуваних показників. Значення цих коефіцієнтів знаходиться в межах від 0 до 1. Чим більше значення коефіцієнта наближається до 1, тим більше обсяг інвестицій залежить від відповідного результаті діяльності науково-технічних систем.

В якості завдання функціонування вітчизняних науково-технічних систем слід розглядати не тільки збільшення обсягів інвестицій в розвиток національного господарства. Важливим опосередкованим результатом їх діяльності є якість інвестицій, тобто ефективність останніх. Зростання рівня ефективності інвестицій в розвиток національного господарства можна визначити за динамікою граничного доходу підприємств підприємницького сектору економіки:

$$
\frac{\Delta Д_{\mathrm{cг}}}{\Delta I} \rightarrow \max
$$

де $\Delta Д_{\text {сг }}-$ збільшення доходів підприємств підприємницького сектору економіки, $\Delta I-$ збільшення інвестицій.
Теоретична конкретизація завдань реалізації державної інноваційної політики розвитку вітчизняних науково-технічних систем дозволить більш якісно уточнити шляхи їх виконання.

\section{Лiтература}

1. Гончаров В. М. Інвестиційні ресурси та ї економічне регулювання [Текст] / В. М. Гончаров, А. А. Навроцький, О. А. Коломийцев. - Донецьк : СПД Куприянов В. С., 2006. - 204 c.

2. Гончаров В. М. Підвищення ефективності інвестиційноінноваційної діяльності підприємства за умов ринкового оточення [Текст] / В. М. Гончаров, Д. В. Солоха, О. А. Федіна, В. К. Мухопадов, О. О. Кузнєцов. - Донецьк : СПД Куприянов В. С. - 2007. - 202 с.

3. Гончаров В. М. Формування стратегії управління інноваційним потенціалом промислового підприємства [Текст] / В. М. Гончаров, С. В. Коверга, Д. В. Солоха, І. С. Грозний та ін. - Донецьк : СПД Куприянов В. С. 2008. - 188 с.

4. Гончаров В. М. Формування організаційно-економічного механізму системи інноваційного розвитку підприємств регіону [Текст] / В. М. Гончаров, Ю. Н. Дерегинський, В. Ю. Припутень та ін. - Донецьк : СПД Куприянов В. С., 2009. - 280 с.

5. Гончаров В. М. Теоретико-методичні основи підвищення інвестиційної привабливості інноваційного потенціалу регіону [Текст] / В. М. Гончаров, Д. В. Солоха, Є. В. Гончаров та ін. - Донецьк : СПД Куприянов В. С., 2010. - 282 с.

6. Гончаров В. Н. Подходы к оценке инвестиционной привлекательности промышленных предприятий [Текст] / В. Н. Гончаров, И. И. Лиски // Энергия. - XXI век. 2006. - № 1. - С. 155-161.

7. Гончаров В. М. Фактори інвестиційної привабливості промислових галузей України [Текст] / В. М. Гончаров, О. О. Горова // Схід. - 2006. - № 1. - С. 35-40.

\section{ЗАДАЧИ СОВЕРШЕНСТВОВАНИЯ ГОСУДАРСТВЕННОЙ ИННОВАЦИОННОЙ ПОЛИТИКИ РАЗВИТИЯ ОТЕЧЕСТВЕННЫХ НАУЧНО-ТЕХНИЧЕСКИХ СИСТЕМ}

\section{И. В. Моргачёв}

В статье конкретизированы задачи совершенствования государственной инновационной политики развитин отечественных научно-технических систем при помощи экономико-математического моделированин.

Ключевые слова: научно-технические системы, государственная инновационная политика, инвестиции, национальное хознйство.

Илья Викторович Моргачёв, кандидат экономических наук, Восточноукраинский национальный университет им. В. Даля.

\section{THE TASKS OF IMPROVING THE STATE INNOVATION POLICY OF THE DEVELOPMENT OF DOMESTIC SCIENTIFIC-TECHNICAL SYSTEMS}

\section{Morgachov}

The article specifies the tasks of perfection of the state innovation policy of the development of domestic scientific-technical systems with the help of economic-mathematical modeling.

Keywords: scientific-technical system and state innovation policy, investments, national economy.

Ilya Morgachov, Ph. D. in Economics, Eastukrainian Nationality University named after Vladimir Dal. 